\title{
Determination of Binding Parameters of Miramistin to Serum Albumin by the Bioluminescent Method
}

\author{
Nickolaj F. Starodub1, Andrey M. Katsev², Elvira R. Abduramanova², Sergey L. Safronyuk², \\ Marina V. Taran 1 \\ ${ }^{1}$ National University of Life and Environmental Sciences of Ukraine, Kiev, Ukraine \\ ${ }^{2}$ Department of General Chemistry, Crimean State Medical University Named after S. I. Georgievsky, \\ Simpheropol, Ukraine \\ Email: nikstarodub@yahoo.com, katsev@mail.ru
}

Received 6 June 2014; revised 22 July 2014; accepted 3 August 2014

Copyright (C) 2014 by authors and Scientific Research Publishing Inc.

This work is licensed under the Creative Commons Attribution International License (CC BY). http://creativecommons.org/licenses/by/4.0/

(c) (i) Open Access

\begin{abstract}
Bioassay based on the luminescent bacteria was used as a new method for the determination of the kinetic constants of ligand binding to the complexion agent. Miramistin as the cationic surface-active antiseptic and serum blood albumin was taken as a model of interacting agent's. It was concluded that this approach might have a wide range for applications, namely, in all cases where the ligand is an inhibitor of bacterial luminescence and its complex dose not effect the intensity of this process.
\end{abstract}

Keywords

Bioluminescent Inhibition Test, Miramistin, Albumin, Association Constants, Determination

\section{Introduction}

A study of quantitative characteristics of drugs interaction with biomolecules is known to have a great scientific and practical importance. Values of the association constants between biologically active substances and biotargets or non-receptor molecules are necessary in understanding molecular mechanisms of physiological and side actions as well as in the determination of the pharmacokinetic properties of medicinal substances [1]-[3].

In this work, a new approach based on the bioluminescent inhibition test (Microtox) has been used to study the biological association. This method is widely utilized by different authors at the rapid estimation of biotoxicity [4]. It is based on the quantitative measurements of the bacterial luminescence intensity that depends on bio- 
cidal properties of studied samples. Based on the features of such biotest, which allows estimating both kinetic and concentration characteristics of bioluminescence, the main aim of this work is to study the interaction and association constants of miramistin as cationic surface-active antiseptic with serum blood albumin. Two simple approaches were found based on the same measurements of bioluminescence intensity over time at various ratios of drug and albumin.

\section{Materials and Methods}

Bioluminescent method: The bioluminescent analysis for studying the interaction of a miramistin as ligand with albumin was fulfilled in the presence of a buffer solution and/or solution of $3 \%$ of $\mathrm{NaCl}$. Reaction mixture was incubated during $15 \mathrm{~min}$ to ensure complete binding and after that the suspension of the luminous bacteria was added. As a result of interaction free ligand with the complexion agent its concentration decreased according to the restoration of the bacteria luminescence.

Determination of binding constant: The data obtained at the registration of bioluminescence in time were used for the determination of the concentration of not bound ligand with the next calculation of the binding constants of ligand-complexing agent. In addition to that, the data obtained on the effect of the ligand and complexing agent on the luminescent bacteria were as basis for the determination of the association constants according to Sketcher method. In this case, a graphical representation of the mass action rule in form of linear dependensies was used at the coordinates $[\mathrm{AM}] /[\mathrm{M}]-[\mathrm{AM}]$ or $[\mathrm{M}] /[\mathrm{AM}]-[\mathrm{M}]$, where $[\mathrm{AM}]$ —equilibrium concentration of the complex albumin-miramistin (mol/l), and [M]—equilibrium concentration of miramistin (mol/l) [5].

Bacterial strains and other materials: In experiments, the luminescent bacteria (Photobacterium leiognathi Sh1) were used. They were taken from the collection of Crimean State Medical University isolated from the Sea of Azov by the authors. Miramistin (benzyldimethyl [3-(myristoylamino) propyl] ammonium) was produced by Darnytsia plant (Ukraine), bovine serum albumin (BSA) by (Sigma, USA). Bioluminescence intensity was measured using a luminometer BLM 8801, production SKTB "Science”, Krasnoyarsk.

\section{Result and Discussion}

As it has been shown in numerous studies many drugs inhibit the bioluminescence of luminescent bacteria in a concentration-dependent manner, thus demonstrating its toxicity, antibacterial properties and other biological activities [6] [7]. It made bioluminescent inhibition test as one of the most common among others ones.

The bioassay based on luminescent bacteria has a set of characteristics, such as an analytical signal physicochemical nature (radiation in the visible region of the spectrum), the simplicity and reproducibility of the experiments, the lowest measurement error and others which bring it to the analytical methods of research. This allows in many cases to use it for the quantitative analysis of substances, inhibitors of bacterial bioluminescence. Moreover, using a luminometer to measure the intensity of bacterial bioluminescence allows receiving not only the concentration but also the time dependences which also gives the opportunity to consider this bioassay as a kinetic method to evaluate binding substances inhibitors bioluminescence with non-inhibitor substances. The latter can include many biopolymers such as proteins, nucleic acids, etc.

The influence of miramistin on bioluminescence was studied in detail previously [8]. It has been established that the cationic surfactant antiseptic nature is a strong inhibitor of bioluminescence. Its effect depends on both time of exposure of bacteria and the $\mathrm{pH}$ of the medium. With increasing $\mathrm{pH}$ it was observed increasing bioluminescence inhibition and reduction of existing relevant concentrations (Figure 1). Thus, the effective concentration $\left(\mathrm{EC}_{50}\right)$ for miramistin at $10 \mathrm{~min}$ bioassay decreased from $2.5 \mathrm{mg} / \mathrm{l}$ at $\mathrm{pH} 5$ to $1.4 \mathrm{mg} / \mathrm{l}$, at $\mathrm{pH} 7 \mathrm{and} 0.8 \mathrm{mg} / \mathrm{l}$ at pH 9. Taking into attention that miramistin molar mass is $440 \mathrm{~g} / \mathrm{mole}$, the concentration of $1 \mathrm{mg} / \mathrm{ml}$ corresponds to $2.3 \mathrm{mmol} / \mathrm{l}$.

Adding BSA to the miramistin samples decreased the inhibitory potency of antiseptic and restored bacterial luminescence intensity. Inhibition curves of miramistin for the bacterial luminescence in the presence of BSA are shown in Figure 2. If in these conditions antiseptic content varies, in certain concentration ranges, the bacteria luminescence remains constant. Above this critical concentration, bioluminescence begins to decline similar to the effect of the drug without the addition of BSA.

Thus, it can be assumed that increasing the concentration miramistin in the presence of BSA initially we observe filling binding sites of the protein and as result of it free antiseptic is absent in solution. With further increases of miramistin concentration, after filling all binding sites, free drug occurs in a solution and demonstrates 


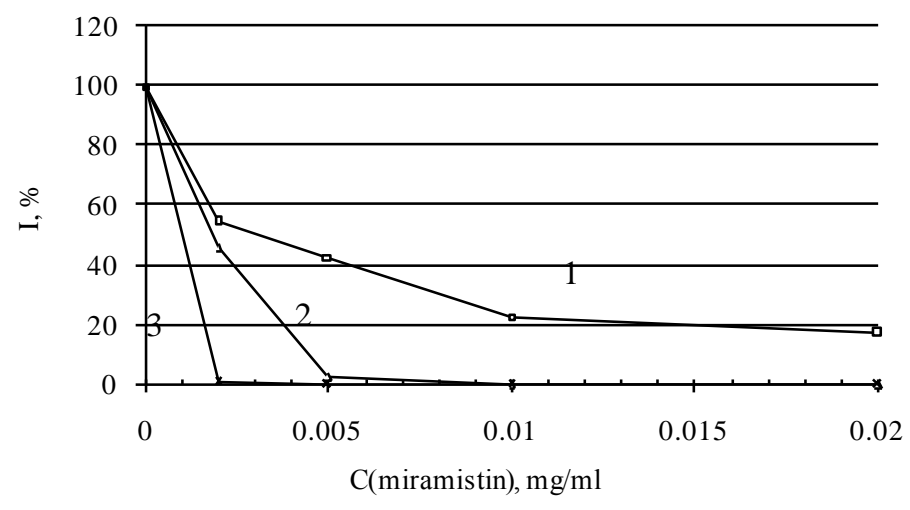

Figure 1. Effect of miramistin on bioluminescent bacteria at the different $\mathrm{pH}: 1-\mathrm{pH}=5 ; 2-\mathrm{pH}=7,0 ; 3-\mathrm{pH}=9,0$.

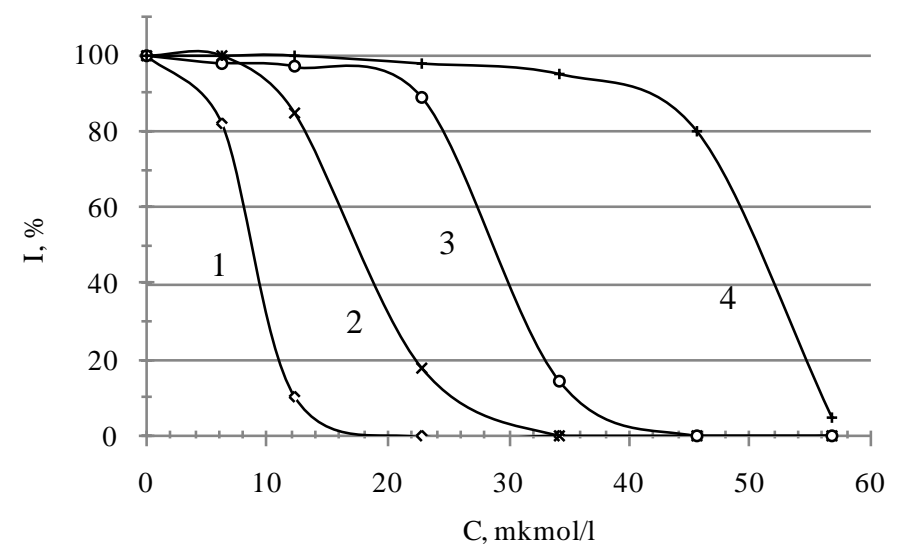

Figure 2. Effect of miramistin on bioluminescence in the presence of BSA (mol/l): $1-0 ; 2-3.9 \times 10^{-6} ; 3-7.7 \times 10^{-6} ; 4-1.5 \times 10^{-5}$.

an inhibitory effect on bacterial bioluminescence. Cannot completely exclude other processes that can cause inhibition of bioluminescence in a complex system included miramistin, BSA and bacteria. For example, there is possible inhibition of bioluminescence by complex BSA-miramistin or redistribution of miramistin between BSA and surface structures of luminous bacteria.

Assuming that the intensity of bioluminescence in samples containing antiseptic and BSA is proportional to the unbound drug protein concentration and knowing the initial concentration it is possible easy to estimate the amount of bound antiseptic. Representing interaction of the drug with BSA (BSA binding site) as A $+\mathrm{M} \leftrightarrows \mathrm{AM}$ the next Equation (1) can be used for calculations of association constants:

$$
\mathrm{K}=\frac{[\mathrm{AM}]}{[\mathrm{M}] \cdot[\mathrm{A}]} \text { or } \mathrm{K}=\frac{[\mathrm{AM}]}{[\mathrm{M}] \cdot(\mathrm{N}-[\mathrm{AM}])}
$$

where $[\mathrm{AM}]$ —equilibrium concentration (mol/l) complex BSA-miramistin; $[\mathrm{M}]$ —miramistin equilibrium concentration (mol/l); [A] — equilibrium concentration of BSA (mol/l); $\mathrm{N}$-the total concentration of binding sites. [AM] numerically is equal to the amount of miramistin bound with the protein at the condition that each molecule is reacted with one of ligand binding site of BSA.

The equilibrium concentration of BSA [A] will be determined as the difference between the total concentration of binding sites $(\mathrm{N})$ and the number of drug-related [AM]. The total concentration of binding sites $(\mathrm{N})$, in turn, can be determined by multiplying the total BSA concentration $\left(\mathrm{C}_{\mathrm{A}}\right)$ on the number of binding sites per molecule (n): $\mathrm{N}=\mathrm{C}_{\mathrm{A}} \cdot \mathrm{n}$.

According to the obtained graphical dependences it was calculated how many molecules miramistin can communicate with one molecule of BSA (Table 1). At the same time it was assumed that the recovery of anti- 
septic inhibited bioluminescence up to $80 \%-100 \%$ means that all of the drugs are fully linked to BSA. At the $90 \%$ of bioluminescence intensity the molar concentrations of BSA and miramistin (mol/mol) were 2.99, 2.99 and 2.66, respectively. At an $80 \%$ bioluminescence which corresponds to the maximum allowable error bioassay in $20 \%$ these values were $3.38,3.15$ and 2.99 , respectively. Thus, the number of binding sites of miramistin in albumin molecule can be considered equal to $3.03 \pm 0.23$.

Thus, knowing the concentration of free miramistin that bacterial bioluminescence intensity determined and the number of molecules bound to the protein can be calculated association constants (Table 2). Taking into account the linear dependency on graphical plots that are in the range of from $60 \%$ to $40 \%$ of bioluminescence and using them as a calibration curve it can determine the equilibrium [M], and the total concentration miramistin $\left(C_{M}\right)$. These concentrations are defined as the projection on the $x$-axis points to the inhibition curves corresponding to the selected bioluminescence intensity (\%). Equilibrium concentration of albumin can be calculated as the difference between its total concentration $\left(\mathrm{C}_{\mathrm{A}}\right)$, multiplied by the number of binding sites $(\mathrm{n})$ and the number of associated miramistin [AM] which, in turn, is defined as the difference between the $C_{M}$ and [M].

The results demonstrated that the association constants vary depending on the concentration of BSA $3.06 \times$ $10^{5} \mathrm{M}^{-1}$ to $1.37 \times 10^{6} \mathrm{M}^{-1}$ and an average of $7.94 \times 10^{5} \pm 3.56 \times 10^{5} \mathrm{M}^{-1}$.

The results obtained during studying the bio effect of complexes of miramistin with albumin were also used to determine the association constants by graphic way. Expression of the concept of mass action, presented above, can be linearized in the coordinates of several types. One of the most common is the method in which the Formula (2) of this concept has the following form:

$$
\frac{[\mathrm{M}]}{[\mathrm{AM}]}=\frac{1}{\mathrm{~N}}[\mathrm{M}]+\frac{1}{\mathrm{~N} \cdot \mathrm{K}}
$$

Table 1. Parameters of binding miramistin with BSA.

\begin{tabular}{cccc}
\hline Level of bioluminescence inhibition & BSA, mol/l & Miramistin, mol/l & $\mathrm{n}$ \\
\hline \multirow{2}{*}{$80 \%$} & $3.85 \times 10^{-6}$ & $1.30 \times 10^{-5}$ & 3.38 \\
& $7.69 \times 10^{-6}$ & $2.42 \times 10^{-5}$ & 3.15 \\
& $1.54 \times 10^{-5}$ & $4.60 \times 10^{-5}$ & 2.99 \\
$90 \%$ & $3.85 \times 10^{-6}$ & $1.15 \times 10^{-5}$ & 2.99 \\
& $7.69 \times 10^{-6}$ & $2.30 \times 10^{-5}$ & 2.99 \\
Middle level & $1.54 \times 10^{-5}$ & $4.10 \times 10^{-5}$ & $3.03 \pm 0.23$ \\
\hline
\end{tabular}

Table 2. Calculation of the association constants of miramistin with BSA.

\begin{tabular}{|c|c|c|c|c|c|c|}
\hline \multirow{2}{*}{ Level of inhibition, \% } & \multicolumn{5}{|c|}{ Concentration, mol/l } & \multirow{2}{*}{ K $10^{5}$} \\
\hline & $\mathrm{C}_{\mathrm{A}} 10^{-6}$ & {$[\mathrm{M}] 10^{-6}$} & $\mathrm{C}_{\mathrm{M}} 10^{-5}$ & {$[\mathrm{AM}] 10^{-6}$} & [A] $10^{-6}$ & \\
\hline \multirow{3}{*}{60} & 3.85 & 8.00 & 1.62 & 8.20 & 3.35 & 3.06 \\
\hline & 7.69 & 8.00 & 2.75 & 19.5 & 3.57 & 6.83 \\
\hline & 15.4 & 8.00 & 4.95 & 41.5 & 4.70 & 11.0 \\
\hline \multirow{3}{*}{50} & 3.85 & 8.50 & 1.75 & 9.00 & 2.55 & 4.15 \\
\hline & 7.69 & 8.50 & 2.82 & 19.7 & 3.37 & 6.88 \\
\hline & 15.4 & 8.50 & 5.05 & 42.0 & 4.20 & 11.8 \\
\hline \multirow{3}{*}{40} & 3.85 & 9.20 & 1.90 & 9.80 & 1.75 & 6.09 \\
\hline & 7.69 & 9.20 & 2.95 & 20.3 & 2.77 & 7.97 \\
\hline & 15.4 & 9.20 & 5.20 & 42.8 & 3.40 & 13.7 \\
\hline
\end{tabular}


and graphically may be presented in linearity form in coordinates $[\mathrm{M}] /[\mathrm{AM}]-[\mathrm{M}]$. To determine the appropriate values $[\mathrm{M}] /[\mathrm{AM}]$ and $[\mathrm{M}]$ it was used the amplification phase miramistin inhibition of bioluminescence that accumulated in the medium during filling of binding sites of the BSA molecule, which corresponds to the initial phase schedule where bioluminescence decreased within $-60 \%$ (Table 3).

At the determination of the binding constant data of Table 3 represented graphically (Figure 3). The intercept on the axis $\mathrm{Y}$ corresponds to the value $\frac{1}{\mathrm{~N} \cdot \mathrm{K}}$ and the slope of the axis $\mathrm{X}$, which can be defined as the ratio of the opposite leg to an adjacent, numerically equal to $\frac{1}{\mathrm{~N}}$. From the data obtained the respective values for the constants were calculated (Table 4). The number of binding sites in the albumin molecule averaged $2.66 \pm 0.36$ and the binding constant is $1.64 \times 10^{6} \pm 4.85 \times 10^{5} \mathrm{M}^{-1}$. It is close to the values given above, which were obtained by calculation.

Using the same experimental data, namely: the association constants miramistin and albumin were determined graphically Sketchard parameters (Figure 4). In this case the law of mass action can be represented as:

Table 3. Results of the graphical determination of the binding parameters of miramistin with BSA.

\begin{tabular}{|c|c|c|c|c|c|c|}
\hline \multirow{2}{*}{ Level of inhibition. \% } & \multicolumn{4}{|c|}{ C. $\mathrm{mol} / \mathrm{l}$} & \multirow{2}{*}[\mathrm{M}]{$/[\mathrm{AM}]$} & \multirow{2}{*}[\mathrm{AM}]{$/[\mathrm{M}$} \\
\hline & $\mathrm{C}_{\mathrm{A}} 10^{-6}$ & {$[\mathrm{M}] 10^{-6}$} & $\mathrm{C}_{\mathrm{M}} 10^{-5}$ & [AM] $10^{-6}$ & & \\
\hline 95 & \multirow{8}{*}{3.85} & 2.00 & 0.90 & 7.00 & 0.29 & 3.50 \\
\hline 90 & & 4.00 & 1.15 & 7.50 & 0.53 & 1.88 \\
\hline 85 & & 5.00 & 1.25 & 7.50 & 0.67 & 1.50 \\
\hline 80 & & 6.00 & 1.40 & 8.00 & 0.75 & 1.33 \\
\hline 75 & & 6.30 & 1.45 & 8.20 & 0.77 & 1.30 \\
\hline 70 & & 7.00 & 1.50 & 8.00 & 0.88 & 1.14 \\
\hline 65 & & 7.70 & 1.55 & 7.80 & 0.99 & 1.01 \\
\hline 60 & & 8.00 & 1.62 & 8.20 & 0.98 & 1.03 \\
\hline 95 & \multirow{8}{*}{7.69} & 2.00 & 1.80 & 16.0 & 0.13 & 8.00 \\
\hline 90 & & 4.00 & 2.30 & 19.0 & 0.21 & 4.75 \\
\hline 85 & & 5.00 & 2.40 & 19.0 & 0.26 & 3.80 \\
\hline 80 & & 6.00 & 2.50 & 19.0 & 0.32 & 3.17 \\
\hline 75 & & 6.30 & 2.60 & 19.7 & 0.32 & 3.13 \\
\hline 70 & & 7.00 & 2.65 & 19.5 & 0.36 & 2.79 \\
\hline 65 & & 7.70 & 2.70 & 19.3 & 0.40 & 2.51 \\
\hline 60 & & 8.00 & 2.75 & 19.5 & 0.41 & 2.44 \\
\hline 95 & \multirow{8}{*}{15.4} & 2.00 & 3.40 & 32.0 & 0.06 & 16.0 \\
\hline 90 & & 4.00 & 4.10 & 37.0 & 0.11 & 9.25 \\
\hline 85 & & 5.00 & 4.45 & 39.5 & 0.13 & 7.90 \\
\hline 80 & & 6.00 & 4.60 & 40.0 & 0.15 & 6.67 \\
\hline 75 & & 6.30 & 4.70 & 40.7 & 0.16 & 6.46 \\
\hline 70 & & 7.00 & 4.80 & 41.0 & 0.17 & 5.86 \\
\hline 65 & & 7.70 & 4.90 & 41.3 & 0.19 & 5.36 \\
\hline 60 & & 8.00 & 4.95 & 41.5 & 0.19 & 5.19 \\
\hline
\end{tabular}




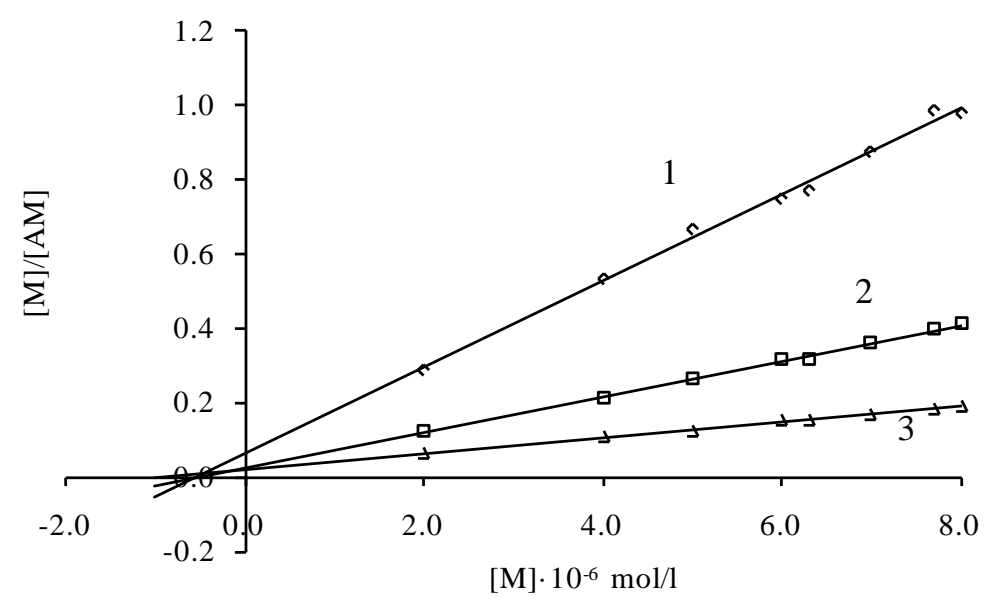

Figure 3. Linearized graphs for the determination of the binding constants of mirimistin with BSA. BSA concentration (mol/l): $1-3.85 \times 10^{-6} ; 2-7.69 \times$ $10^{-6} ; 3-1.54 \times 10^{-5}$.

Table 4. Results of the determination of the binding constants of mirimistin with BSA by graphical way.

\begin{tabular}{cccc}
\hline $1 /(\mathrm{N} \cdot \mathrm{K})$ & $1 / \mathrm{N}$ & $\mathrm{n}$ & $\mathrm{K}$ \\
\hline 0.060 & $1.14 \times 10^{5}$ & 2.28 & $1.91 \times 10^{6}$ \\
0.025 & $4.82 \times 10^{4}$ & 2.70 & $1.93 \times 10^{6}$ \\
0.020 & $2.16 \times 10^{4}$ & 3.00 & $1.08 \times 10^{6}$ \\
\hline
\end{tabular}

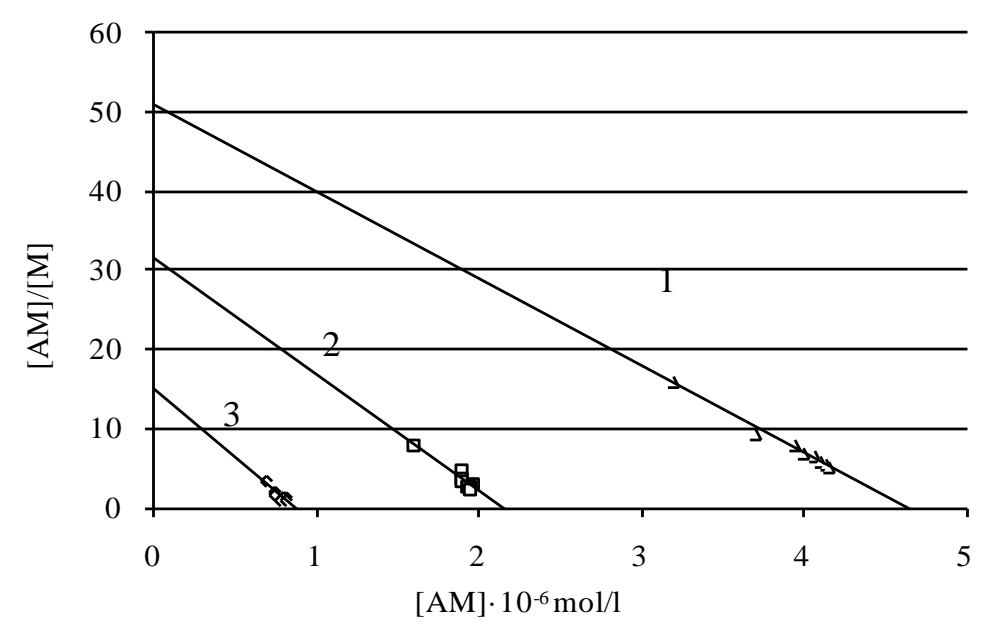

Figure 4. Sketcher graphics for the determination of association constants for miramistin with BSA. BSA concentration (mol/l): $1-3.85 \times 10^{-6} ; 2-7.69 \times$ $10^{-6} ; 3-1.54 \times 10^{-5}$.

$$
\frac{[\mathrm{AM}]}{[\mathrm{M}]}=\mathrm{K} \cdot \mathrm{N}-\mathrm{K} \cdot[\mathrm{AM}]
$$

and for the linearization of graphical dependences the coordinates of $[\mathrm{AM}] /[\mathrm{M}]-[\mathrm{AM}]$ should be used. While the intercept on the axis $\mathrm{Y}$. is equal to the $\mathrm{K} \cdot \mathrm{N}$. and the intercept of the $\mathrm{X}$-axis is equal to $\mathrm{N}$. The slope of the $\mathrm{X}$ axis is $\mathrm{K}$ (Figure 4).

As can be seen from Table 5 which shows the results of the graphical determination of the association con- 
stants and the number of binding sites according to Sketcher method the average value of $\mathrm{K}$ was $1.42 \times 10^{6} \pm$ $2.86 \times 10^{5} \mathrm{M}^{-1}$ and the number of binding centers $-2.71 \pm 0.33$ which is consistent with the above findings of other methods.

Similar experiments have been done and at the varying the concentration of BSA and at a constant concentration miramistin.

As seen from Table 6 these data are consistent with the results shown in Table 4, Table 5.

Obtained in this work values for $\mathrm{n}$ index practically coincide with the available literature data on the capacity of the center of fatty acid binding by albumin molecule [9] [10].

The interaction of miramistin with this center was also confirmed by additional experiments on competitive interactions antiseptic and myristicacid with BSA (Figure 5). In the presence of myristic acid binding antiseptic with protein decreased that accompanied a change in form of curves and increased the inhibitory effect of mirimistin on bioluminescence. But myristic acid in the used concentrations did not affect the bacteria bioluminescence.

Table 5. Binding constants of miramistin with BSA determined by graphical way according to Sketcher method.

\begin{tabular}{cccc}
\hline $\mathrm{N}$ & $\mathrm{K} \cdot \mathrm{N}$ & $\mathrm{n}$ & $\mathrm{K}$ \\
\hline $9.00 \times 10^{-6}$ & 15.0 & 2.34 & $1.67 \times 10^{6}$ \\
$2.20 \times 10^{-5}$ & 32.0 & 2.80 & $1.49 \times 10^{6}$ \\
$4.70 \times 10^{-5}$ & 51.0 & 2.99 & $1.11 \times 10^{6}$ \\
\hline
\end{tabular}

Table 6. Common data of calculation of association constant for miramistin with BSA.

\begin{tabular}{cccc}
\hline & & $\mathrm{n}$ & \\
Constants & 3 & 2.5 & \\
\cline { 2 - 4 } $\mathrm{K}_{1}$ & $3.08 \times 10^{5}$ & $5.67 \times 10^{5}$ & $2.40 \times 10^{6}$ \\
$\mathrm{~K}_{2}$ & $2.62 \times 10^{5}$ & $5.03 \times 10^{5}$ & $2.06 \times 10^{6}$ \\
K(average) & & $1.02 \times 10^{6} \pm 9.53 \times 10^{5}$ & \\
\hline
\end{tabular}

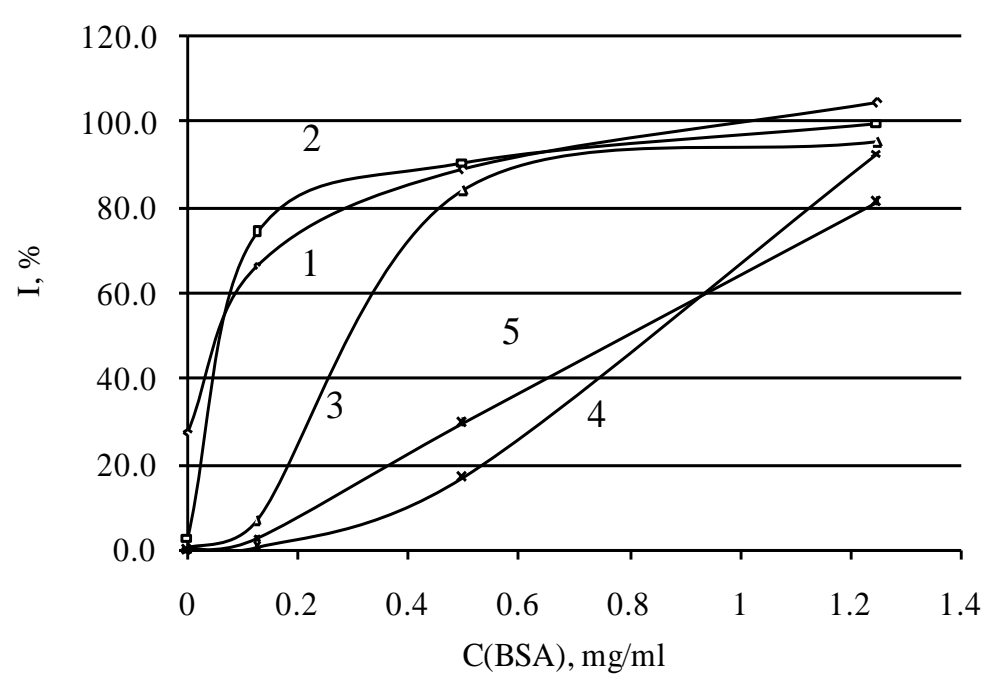

Figure 5. Changes of miramistin binding ( $5 \mathrm{mkg} / \mathrm{ml})$ with BSA at the presence of myristic acid. Myristic acid (mg/ml): $1-5-0 ; 0.001 ; 0.004 ; 0.01$ and 0.02 . respectively. 


\section{Conclusions}

Luminescent bacteria were studied to be used as an analytical tool to determine the concentration of free unbound drug-cationic surface-active antiseptic miramistin by estimation of bioluminescence inhibition level. Measuring luminescence intensity in compound solutions containing albumin and miramistin gives opportunity to determine quantitative parameters of their interaction such as association constants, numbers of binding centers in the protein molecule. Using additional kinds of ligands (myristic acid in this study), such an analytical approach allows predicting the type of binding centers in complexion agent.

To evaluate the association constants, a few calculating and graphic methods were developed. All they show similar results. It should be mentioned that such bioassay method based on the luminescent bacteria is a new quantitative analytical tool to study biological and chemical interaction which has not been previously described. Moreover, this approach may have a wide range of additional applications. It can be used in many cases where ligand is an inhibitor of bacterial luminescence and its complex does not effect the intensity light emission [11]-[13].

\section{References}

[1] Pahikkala, T., Airola, A., Pietil, S., Shakyawar, S., Szwajda, A., Tang, J. and Aittokallio, T. (2014) Toward More Realistic Drug-Target Interaction Predictions. Briefings in Bioinformatics, April 9. (In Press).

[2] Bourassa, P., Thomas, T.J. and Tajmir-Riahi, H.A. (2014) Locating the Binding Sites of Antitumor Drug Tamoxifen and Its Metabolites with DNA. Journal of Pharmaceutical and Biomedical Analysis, 95, 193-199. http://dx.doi.org/10.1016/j.jpba.2014.02.028

[3] Sykes, D.A., Parry, C., Reilly, J., Wright, P., Fairhurst, R.A. and Charlton, S.J. (2014) Observed Drug-Receptor Association Rates Are Governed by Membrane Affinity: The Importance of Establishing "Micro-Pharmacokinetic/Pharmaco-Dynamic Relationships” at the B2-Adrenoceptor. Molecular Pharmacology, 85, 608-617.

[4] Lopez-Roldan, R., Kazlauskaite, L., Ribo, J., Riva, M.C., Gonzбlez, S. and Cortina, J.L. (2012) Evaluation of an Automated Luminescent Bacteria Assay for in Situ Aquatic Toxicity Determination. Science of the Total Environment, 440, 307-313. http://dx.doi.org/10.1016/j.scitotenv.2012.05.043

[5] Varfolomeev, S.D. and Zaitsev, S.V. (1982) Kinetic Methods in Biochemical Investigations. Moscow University, Moscow, $342 \mathrm{p}$.

[6] Roda, A., Guardigli, M., Mishelini, E., et al. (2003) Analytical Bioluminescence and Chemiluminescence. Analytical and Bioanalytical Chemistry, 75, 462-470.

[7] Parvez, S., Venkataraman, C. and Mukherji, S. (2006) A Review on Advantages of Implementing Luminescence Inhibition Test (Vibrio fischeri) for Acute Toxicity Prediction of Chemicals. Environment International, 32, 265-268.

[8] Katsev, A.M. and VIu, S. (2002) Interaction of Cationic Surface-Active Antiseptics and Serum Albumin by the Bacterial Bioluminescence Method. Clinical Laboratory Diagnostics, 4, 39-41.

[9] Luik, A.I. and Lukianchuk, V.D. (1984) Serum Albumin and Biotransport of Poison. Medicina, Moscow, 224 p.

[10] Miller, Y.I. (1993) Binding of Xenobiotics by Serum Albumin. Clinical Laboratory Diagnostics, 1, 34-40.

[11] Katsev, A.M., Onuchina, I.G., Gordienko, A.I. and Beloglazov, V.A. (2001) Bioluminescent Method for Lipopolysaccharide Determination. Tavrichesky Medico-Biological Bulletin, 4, 120-123.

[12] Katsev, A.M. and Vlu, S. (2001) Method for Estimation of Binding capacity of Seralbumin. Tavrichesky Medico-biological Bulletin, 4, 147-150.

[13] Katsev, A.M., Onuchina, I.G., Gordienko, A.I. and Beloglazov, V.A. (2002) Study of the Binding between Bacterial Lipopolysaccharides and Polymyxin by a Bioluminescent Method. Ukrainian Biochemical Zhurnal, 74, 103-107. 
Scientific Research Publishing (SCIRP) is one of the largest Open Access journal publishers. It is currently publishing more than 200 open access, online, peer-reviewed journals covering a wide range of academic disciplines. SCIRP serves the worldwide academic communities and contributes to the progress and application of science with its publication.

Other selected journals from SCIRP are listed as below. Submit your manuscript to us via either submit@scirp.org or Online Submission Portal.
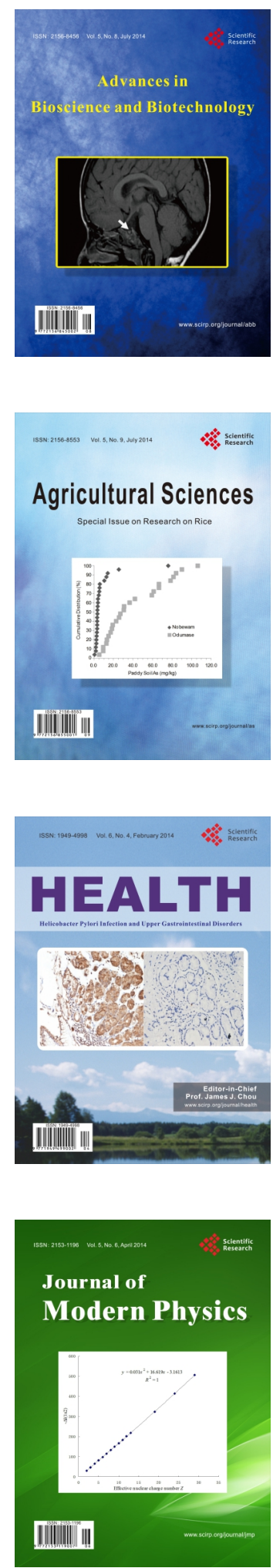
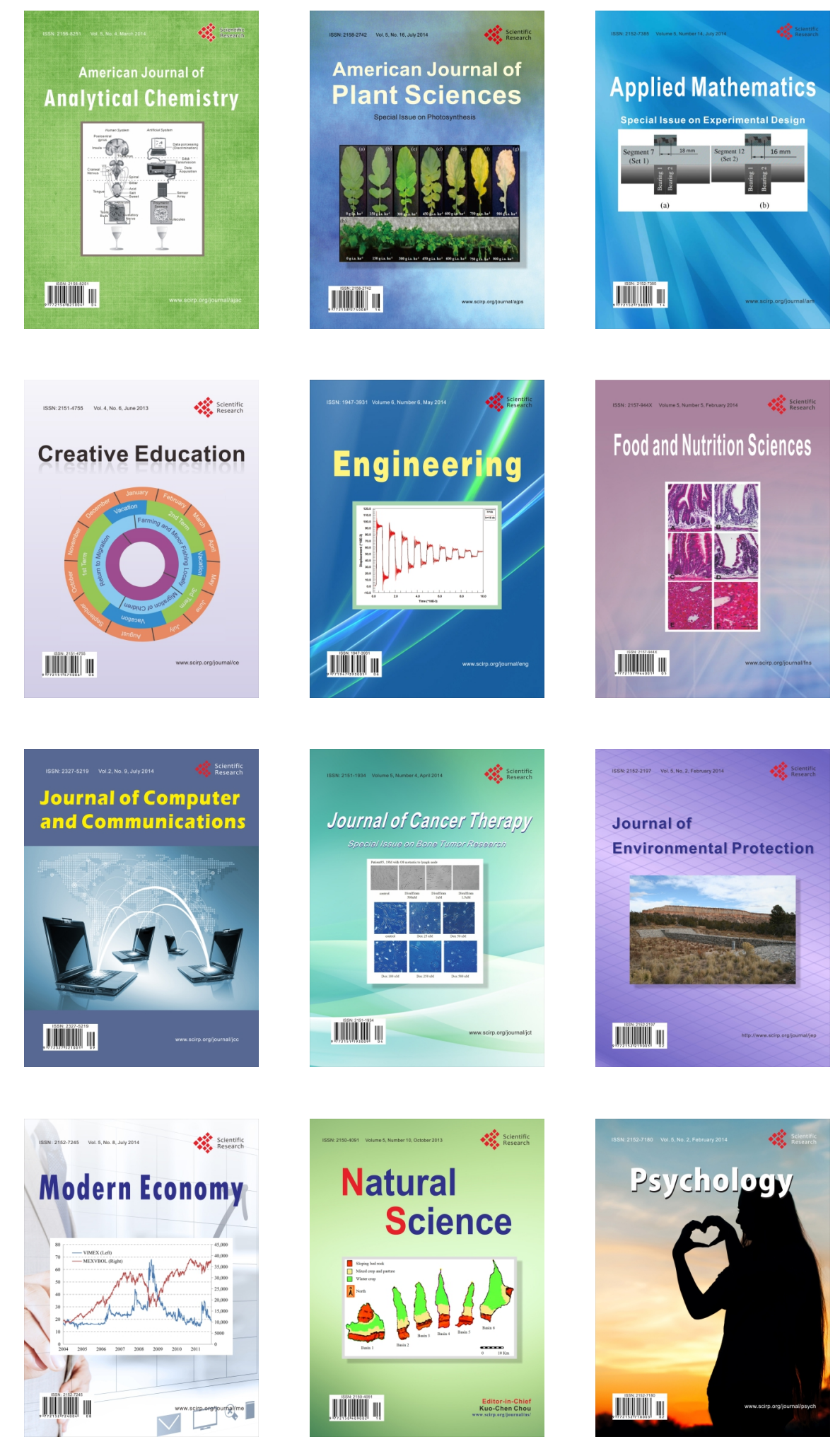